\title{
A MUNDANIZAÇÃO DA FILOSOFIA: MARX E AS ORIGENS DA CRÍTICA DA POLÍTICA
}

Álvaro BIANCHI ${ }^{1}$

- RESUMO: O objetivo deste artigo é apresentar as origens da crítica marxiana da política. Encontrando seu lugar entre os anos de 1842 e 1843 essa crítica nasce no interior de uma revisão da filosofia hegeliana e assume uma primeira forma como crítica filosófica da política. A crítica da política desenvolvida por Marx era, assim, rigorosamente, um empreendimento filosófico, mas de uma filosofia que assumia o mundo como seu objeto e se vertia para fora de si própria manifestando-se externamente como uma crítica da sociedade da época e como uma negação da política existente.

- PALAVRAS-CHAVE: Marx; Hegel; ideologia alemã.

\footnotetext{
"A verdadeira crítica analisa não as respostas, mas as questões" (MARX \& ENGELS, 1980, p.183).
}

O conjunto da obra de Marx pode ser lido como um empreendimento crítico, o que é evidenciado pela recorrência com a qual a idéia de crítica aparece nos títulos e subtítulos de suas obras. ${ }^{2}$ Não há novidade nessa afirmação e muitas vezes ela foi repetida. Mas a obra de Marx é daquelas nas

1 Professor Assistente Doutor do Departamento de Ciência Política e do Programa de Pós-Graduação em Ciência Política da Universidade Estadual de Campinas-Unicamp e pesquisador do Centro de Estudos Marxistas (Cemarx/Unicamp). Artigo recebido em jul/06 e aprovado para publicação em nov/06.

2 De Zur Kritik der Hegelschen Rechtsphilosophie, de 1843 (título atribuído por Riazanov na primeira edição do manuscrito em 1927) à Kritik des Gothaer Programms, de 1875 
quais sua complexidade conspira contra o óbvio. Os lugares comuns a seu respeito são comuns, mas são, também, não lugares. Raramente tem sede no próprio texto. Se ao invés de nos limitarmos aos títulos e subtítulos da obra de Marx nos interrogramos sobre esse óbvio algumas questões se põem: Qual o sentido da crítica marxiana? Qual é seu objeto? Qual é seu método?

Este artigo não pretende responder essas questões de modo abrangente. Limita a investigação sobre o objeto da crítica ao âmbito da política e reduz a pesquisa àquele momento da produção teórica de Marx no qual a política é assumida explicitamente como objeto da crítica. É, pois das origens da crítica da política que aqui se trata. A escolha do tema e do período não tem por objetivo, entretanto, estabelecer a continuidade ou a ruptura entre essas obras e as obras da maturidade, nem instituir "o momento preciso" no qual Marx passou a ser ele próprio. A ênfase não será posta no início ou no fim do percurso e sim no próprio caminho. É apenas nele que se torna possível identificar as questões que moviam o autor.

\section{Prolegômenos à crítica da política: a filosofia crítica}

Por mais que uma leitura retrospectiva da obra de Marx possa se surpreender é preciso afirmar que o programa de pesquisa marxiano era, em 1841, um programa estritamente teórico no qual a realização da filosofia deveria limitar-se a sua forma filosófica. A práxis filosófica deveria, assim, permanecer como prática teórica se quisesse se realizar.

Foi a partir dessa perspectiva que Marx enfrentou o legado teórico de Hegel por meio uma crítica teórica que assumia a forma de uma crítica interna. A questão primeira posta por esse legado dizia respeito à autenticidade do pensamento hegeliano: a censura prussiana teria imposto ao velho mestre também uma autocensura? Desta questão nascia uma outra mais importante para o desenvolvimento do campo filosófico pós-hegeliano: essa autocensura não teria levado Hegel a sabiamente dissimular suas verdadeiras opiniões a respeito da política e da religião, revelando estas de modo apenas cifrado? Para a filosofia alemã esta era a grande questão após a morte de Hegel em 1831, quando o efeito agregador do velho mestre cessava de existir justamente no exato momento em que sua vida chegava ao fim e as dissidências interpretativas surgiam com força.

Respondendo afirmativamente a estas duas questões surgia, entre os jovens hegelianos, a tese de um Hegel esotérico, contraposto a outro exotérico. O grande filósofo alemão teria, de acordo com essa tese, evitado manifestar suas verdadeiras idéias políticas e religiosas sempre que estas estivessem em contradição com as idéias predominantes em seu tempo. Sua obra teria, desse modo, um caráter exotérico dado ao conhecimento do pú- 
blico leitor. Mas haveria, entretanto, outro Hegel, este liberal e até mesmo ateu, que de modo dissimulado apresentaria seu pensamento esotérico para aqueles capazes de decifrá-lo. ${ }^{3}$ Era esse Hegel esotérico que aparecia na paródia escrita por Bruno Bauer com a colaboração de Karl Marx, Die Posaune des Jüngsten Gerichts über Hegel den Atheisten et l'antichristen: ein Ultimatum (A trombeta do julgamento final contra Hegel, o ateu e o Anticristo: um ultimatum), publicada anonimamente em 1841 (BAUER, 1972; ver a respeito dessa obra os comentários de BAATSCH, 1972 e ROSSI, 1971, p.91-126).

Em Die Posaune, Bauer assumia as vestes e o discurso de um teísta ortodoxo que procurava demonstrar o papel de Hegel como corruptor do cristianismo, bem como seu ateísmo. Era, portanto, o caráter esotérico do pensamento do velho mestre que se revelava no ensurdecedor solo do trombetista: "Com Hegel veio o Anticristo e nele a visão do Apocalipse 'realizou-se'" (BAUER, 1972, p.32). A realização da filosofia hegeliana era assim apresentada como a dissolução e o fim da ordem religiosa e política existente. Ao fazer essa denúncia procurava o teísta ortodoxo chamar a atenção dos "governos cristãos (..) do perigo mortal que ameaça a ordem existente e, acima de tudo, a religião, único fundamento do Estado" (ibidem).

Bauer, por meio do trombetista aproveitava para ajustar as contas com o teísmo especulativo dos velhos hegelianos. Pois estes, segundo Die Posaune, também estariam contaminados pela doença racionalista e filosófica que atingia os jovens discípulos do Anticristo. Quisessem defender a religião e o Estado como diziam, precisariam romper com seu velho mestre. E não adiantaria os jovens hegelianos construírem um álibi para o seu inspirador e afirmarem a necessidade de liberar os princípios hegelianos dos estreitos limites do sistema. Pois o mal, para o enfurecido teísta, não radicaria nem na dialética nem no sistema que a aprisionava, ele teria morada no próprio ato de filosofar partilhado por velhos e jovens hegelianos. Nele residiria a ameaça "à vida cristã".

Para o trombetista, essa ameaça seria decorrência do caráter revolucionário da filosofia hegeliana. Colocando o saber e a teoria na mais elevada posição, Hegel teria situado a filosofia "acima de seu tempo", ocupando assim a posição de comando da História (idem, p.104). Embora alguns jovens hegelianos afirmassem que o filósofo alemão estaria absorvido unicamente pela teoria e não estivesse preocupado em prolongar a teoria em práxis, o trombetista denunciava: "sua teoria é, nela própria, práxis, porque ela é a mais perigosa, vasta e destrutiva. Ela é a própria Revolução" (ibidem).

3 Sobre o debate em torno dessa tese ver HONDT (1968), ILTLING (1977), LOSURDO (1998) e CINGOLI (2004-2005). 
A apropriação por Bauer de grande número de passagens da obra de Hegel e uma perspicaz utilização destas permitia-lhe apresentar suas próprias idéias a respeito. Bauer destacava, por meio dessas citações, o caráter crítico da filosofia. Colocando-se acima do tempo e da ordem estabelecida, esta poderia libertar o espírito de modo a permitir a transformação dos antigos valores em uma nova forma e em novos valores. Era essa a razão pela qual a filosofia se colocava na esfera política e procurava superar as condições existentes quando estas contradiziam a consciência de si. Segundo Bauer:

A filosofia é, consequentemente, a crítica daquilo que existe. (..) Aquilo que é aí e aquilo que deve ser são distinguidos. Mas o dever ser é unicamente o verdadeiro, o justificado, devendo ser valorizado e conduzido à dominação e à potência. Ele deve conduzir 'seu contrário' a termo (..) ela deve, então, passar à ação, à oposição prática, e isso não apenas tardiamente ou por vias sinuosas, mas é preciso que de maneira imediata um princípio teórico transforme-se em práxis e ação. (idem, p.105)

Era, pois, como atividade crítica que a filosofia se realizaria. Para Bauer a filosofia encerraria sua própria práxis, ela era, em si, revolucionária. A práxis não tinha, portanto, um lugar independente ou externo à teoria. A práxis era o devir ação da teoria, a teoria realizada. Era essa também a perspectiva de Marx quando da redação de sua tese sobre a filosofia da natureza de Demócrito e Epicuro. Destacava na ocasião que a libertação do espírito implicaria em sua transformação em energia prática e vontade que se voltaria contra a realidade mundana (MARX \& ENGELS, 1980, p.79). Mas essa transformação da filosofia em energia prática não tinha como conseqüência uma autonomização da práxis. Marx esclarecia a esse respeito o caráter filosófico da crítica e sua relação com a práxis. Como atividade prática a filosofia era práxis teórica: "a práxis da filosofia é ela própria teórica. É a crítica que compara a existência singular à essência, a realidade particular à idéia" (ibidem).

A atividade teórica não deixava, entretanto, de ser uma práxis histórica. Ao contrário de Hegel, para quem o desenvolvimento da filosofia era exclusivamente lógico, para Marx era na história que a prática teórica encontrava seu lugar. ${ }^{4}$ Nesse ponto nevrálgico afirmava-se a distância que guardava sua pesquisa daquela história da filosofia levada a cabo por Hegel. Apesar de todos os méritos deste último, e de ter servido confessadamente como ponto de partida para a investigação marxiana, estaria preso a uma concepção autolimitada do especulativo. Desse modo, ao fixar uma

4 Sobre a historicidade dos sistemas filosóficos na análise marxiana da filosofia grega, ver RENAULT (1995, p.24-31) 
chave de leitura retrospectiva teria lhe escapado a importância que a obra dos pós-aristotélicos revestiria "para a história da filosofia grega e para o espírito grego em geral" (idem, p.24). Ao avaliar essa importância historicamente, o jovem Marx chegava a resultado diferente, destacando o lugar das escolas epicurista, estóica e cética na conformação histórica da autoconsciência humana: "Esses sistemas são a chave da verdadeira história da filosofia grega" (idem).

A historicidade resgatada permitia à filosofia torna-se profana, refletindo sobre o mundo e pertencendo ao mundo sobre o qual pensava. Era nessa relação de reflexão que a filosofia estabelecia com o mundo que as contradições presentes neste e naquela se revelavam:

Conseqüentemente, o filosofar-se do mundo é também uma mundanização da filosofia, que o realizar-se desta é, ao um mesmo tempo seu perder-se, que aquilo que ela combate externamente é a sua própria deficiência interna, que nessa luta ela própria cai nos defeitos que combate nos adversários e que essa elimina seus defeitos apenas caindo neles. (idem, p.80)

A questão não está limitada a esse texto do ano de 1841. Em uma proposição presente em artigo publicado na Rheinische Zeitung em 14 de julho de 1842, Marx iria radicalizar, ainda dentro da perspectiva própria dos jovens hegelianos, o caráter mundano da filosofia. A mundanização da filosofia assumia nesse artigo o caráter de um programa de realização da própria filosofia. Pois tal mundanização implicaria não apenas a interiorização do conteúdo do mundo pela filosofia sob a forma de reflexão a respeito deste, como, também, um voltar-se para fora de si própria, manifestando-se externamente e convertendo-se na "filosofia em geral" na "filosofia do mundo atual". Segundo Marx,

as filosofias não brotam da terra como os cogumelos: elas são o fruto de seu próprio tempo e do próprio povo, cujas seivas mais sutis, mais preciosas e invisíveis confluem nas idéias filosóficas. O mesmo espírito que com as mãos da indústria constituía as ferrovias constrói nos cérebros dos filósofos os sistemas filosóficos. A filosofia não habita fora do mundo, assim como o cérebro; embora não resida no estômago, não por essa razão encontra-se fora do homem. (idem, p.197)

A partir dessa relação na qual a filosofia realizada enfrentava o mundo os filósofos chegariam, segundo Marx, a um postulado dual: por um lado a autoconsciência da contradição lhes impeliria a voltar-se contra o próprio mundo e seu caráter irracional; por outro lado, lhes conduziria a voltar-se contra a própria filosofia e suas insuficiências. Essa dualidade da autoconsciência filosófica produziria uma importante clivagem teórico-política que não era senão a divisão que se estabelecia no próprio seio do hegelianismo. 
Assim, o "partido liberal", vinculado ao próprio "conceito e princípio da filosofia", caracterizava-se pela crítica, ou seja, "pelo movimento da filosofia ao exterior", movimento esse que reconhecia os limites da filosofia como defeitos do próprio mundo que deviam ser superados filosoficamente, enquanto a "filosofia positiva" tinha como característica dominante o nãoconceito, "o momento da realidade", o movimento de "voltar a filosofia a seu próprio interior", movimento esse que reconhecia os defeitos desta como sendo imanentes à própria filosofia (cf. idem, p.80).

A afirmação de que a "filosofia positiva" prendia-se ao "momento da realidade" tinha assim um caráter polêmico, pois não é da filosofia positiva representada por C. H. Hermann, I. H. Fichte, J. Sengler e C. P.Fischer que Marx fazia referência, como pareceria a primeira vista, e sim à leitura que a direita hegeliana fazia do prefácio de Grundlinien der Philosophie des Rechts (Linhas fundamentais da Filosofia do Direito) de Hegel - "o que é racional é real e o que é real é racional" (HEGEL, 1995, p.41) - com vistas a justificar a racionalidade do real e, portanto, seu caráter universal. A identificação da direita hegeliana com a filosofia positiva tinha, desse modo, o intuito de reivindicar para o "partido liberal" a exclusividade da representação do legado. Se o legado era reivindicado era porque o mesmo juízo negativo não era feito a respeito do velho mestre. Ao contrário de Bauer, que parecia alimentar a tese de um Hegel esotérico, Marx, reconhecia como perfeitamente concebível que Hegel incorresse

nesta ou naquela aparente incoerência, neste ou naquele acomodamento, e que ele próprio possa disto ser consciente. Mas do que ele não é consciente é que a possibilidade desse aparente acomodamento tenha sua raiz mais profunda na insuficiência, ou insuficiente exposição, de seu próprio princípio. ${ }^{5}$ Assim, pois, se um filosofo procede realmente por acomodamento, seus discípulos devem explicá-lo com base em sua consciência essencial interna aquilo que para ele próprio tomava a forma de uma consciência exotérica. (MARX \& ENGELS, 1980, p.79, grifo do autor)

A solução apresentada por Marx para a distinção entre um Hegel esotérico de outro exotérico é, pois, original e difere do tratamento dado á questão por Bauer. O reconhecimento de uma distinção entre aquilo que Hegel exporia ao público e seu verdadeiro pensamento não deveria levar a considerar

5 Ouve-se aqui o eco da Zur Kritik der Hegelschen Philosophie (Contribuição à crítica da filosofia de Hegel), de Feuerbach: "A filosofia hegeliana é então o apogeu da filosofia sistemática de tipo especulativo. Por isso temos descoberto e explicado o fundamento do começo da Lógica. Tudo deve ser exposto (provado), quer dizer, passar exaustivamente pela exposição. A exposição faz a abstração do saber anterior à exposição; ela deve começar por um começo absoluto. Mas aqui aparece imediatamente o limite da exposição. O pensar existe anteriormente à exposição do pensar" (FEUERBACH, 1960, p, 41) 
partes de sua obra como inautênticas. ${ }^{6}$ Pois este pensamento exotérico deveria ser explicado com base na consciência interna do próprio Hegel e nas razões que o teriam levado a proceder a uma acomodação com o poder e a ordem, razões essas que não deveriam ser procuradas no medo da perseguição e da repressão policial e sim "na insuficiência, ou insuficiente exposição" da teoria, na sua própria configuração interna (cf. tb. LOSURDO, 1998, p.24).

Pretendia Marx desenvolver essa crítica, juntamente com Bruno Bauer sob a forma de uma continuação de Die Posaune que deveria tratar da crítica hegeliana à "arte cristã" e ao direito. Apenas Bauer completou sua parte, publicando-a em junho de 1842 com o título Hegels Lehre von der Religion und der Kunst von dem Standpunkte des Glaubens aus beurteilt. Marx mencionou, em carta a Arnold Ruge de 5 de março de 1842, o "ensaio sobre a arte cristã" que estava escrevendo como continuação de Die Posaune e fez referência, também, a outro artigo, dedicado a uma "crítica ao direito natural hegeliano" no que concernia à "constituição interna", cujo ponto central seria a luta contra a "monarquia constitucional, enquanto híbrido que se contradiz e se nega completamente" (MARX \& ENGELS, 1980, p.400). Uma nova referência foi feita em 20 de março a esses artigos, anunciando que a redação de seu ensaio de crítica à filosofia do direito hegeliano não poderia ser finalizado em breve e que o trabalho sobre a "arte cristã" ficaria pronto em meados de abril (idem, p.404).

Não há mais referências na correspondência com Ruge ao artigo sobre a filosofia do direito hegeliano e esse projeto seria retomado apenas em 1843, mas em novas bases. Em compensação, Marx informava a seu interlocutor que em breve lhe enviaria quatro ensaios: "1) 'Sobre a arte religiosa', 2) 'Sobre os românticos', 3) 'O manifesto filosófico da escola histórica do direito', 4) 'Os filósofos positivos'” (idem, 1980, p.406). Destes, apenas o artigo referente a escola histórica do direito foi efetivamente concluído e publicado, na Rheinische Zeitung (cf. idem, pp.206-14). Uma última menção ao texto sobre a "arte cristã" foi feita em carta de 9 de julho, anunciando que "não havia conseguido elaborá-lo profundamente, como a questão requeria" (idem, p.407).

Uma série de circunstâncias biográficas teria atrasado o trabalho de Marx sobre as questões propostas. Mas para além de tais questões, parece ser relevante o fato de que tenha, cada vez mais, se dedicado a sua atividade de publicista ocupado com os temas da política contemporânea e da crítica filosófico-política e se distanciado da crítica filosófico-religiosa considerada por Bauer, Feuerbach e outros jovens hegelianos como a crítica por

6 É o que faz Ilting (1977) com as Grundlinien der Philosophie des Rechts (Linhas fundamentais da Filosofia do Direito) de Hegel, ao considerá-las espúrias e inautênticas. 
excelência. Era essa crítica filosófico-política "daquilo que existe" que o movia em seus artigos sobre a lei de censura na Prússia e o debate sobre a liberdade de imprensa, nos quais comparava a existência singular da legislação prussiana a sua essência, revelando as contradições existentes nas instituições políticas (TEEPLE, 1984, p.42).

De um ponto de vista filosófico, ou seja, do "ponto de vista da idéia", afirmava Marx a esse respeito em artigo publicado em 12 de maio na Reinische Zeitung, a liberdade de imprensa era um aspecto da própria Idéia, da liberdade, e, portanto, um bem positivo, "enquanto que a censura é um aspecto da não-liberdade, a polêmica de uma concepção da aparência contra a concepção da essência, portanto uma natureza puramente negativa" (MARX \& ENGELS, 1980, p.153). A essência da liberdade de imprensa era a "natureza enérgica, racional e moral da liberdade. A da imprensa censurada é a incoerente deformidade da não-liberdade, é um monstro civilizado, um aborto perfumado", anunciava (idem, p.157).

A aparência denunciada era a aparência liberal do governo prussiano e a contradição revelada aquela que se estabelecia entre o conceito racional de liberalismo e a irracionalidade do real, ou seja, a que se manifestava na inadequação do liberalismo real ao ideal do liberalismo. Segundo Marx, a nova Instrução sobre a censura, editada pelo governo prussiano em 24 de dezembro de 1841, aparecia como uma regulamentação da liberdade de imprensa. Mas a liberdade de imprensa só poderia ser a forma da censura como expressão de "um pseudo-liberalismo" (idem, p.116). ${ }^{7}$ Seu primeiro artigo sobre a questão, publicado apenas em fevereiro de 1843 nas Anedokta zur neuesten deutschen Philosophie und Publizistik, um ano após sua redação, denunciava de modo insistente essa aparência e revelava o caráter arbitrário de uma legislação que sancionava não os atos enquanto tais e sim a intenção daquele que os realizava. Mas leis baseadas em tais intenções não constituíam normas objetivas, eram "leis do terrorismo", "leis de um partido contra outro" (idem, 1980, p.116). Apesar de terem a forma de leis eram, na sua essência, privilégios particulares cuja defesa colocava o governo contra aquilo que ele próprio representava, a sociedade. E assim como a forma legal da lei encontrava-se em contradição com seu conteúdo, o Estado constituía-se no inverso de si:

Como na lei tendenciosa a forma legal contradiz o conteúdo, como o governo do qual emanam coloca-se contra aquilo que ele próprio representa, isto é, contra o modo

\footnotetext{
7 Dizia o texto das Instruções: "para liberar imediatamente a imprensa das infundadas restrições, que não correspondem às intenções soberanas, sua majestade o Rei, com um supremo decreto enviado o dia 10 do corrente mês ao Real Ministério do Estado, expressou decididamente sua desaprovação perante toda restrição ilícita da atividade publicista". (Apud MARX \& ENGELS, 1980, p.105).
} 
de pensar contrário ao Estado, assim também em particular o governo constitui quase o inverso de suas leis porque utiliza duas medidas. Para uns é justo aquilo que para outros é injusto. Assim, suas leis são o contrário daquilo que as torna leis. (idem, p.117)

Na conclusão a crítica assumia seu caráter negativo. A única "cura radical para a censura" possível era para Marx, sua própria abolição. Nenhuma outra poderia dissolver a contradição que se colocava nela própria. Mas a dissolução da censura apontava para a dissolução do próprio Estado. Pois também ele constituía-se no inverso daquilo que o "Estado ético" dizia ser e se esse "Estado coativo" quisesse tornar-se legal, ele próprio se anularia (idem, p.127). Para evitar a antecipação de um tema que aparecera na obra marxiana apenas em período posterior - o tema do "fim do Estado" -, é preciso chamar a atenção que ele estava aí escrevendo a respeito da anulação de um Estado existente que violava seu conteúdo racional e que já era, portanto, um não-Estado perante seu conceito. Era sobre a "anulação" do "Estado coativo", que Marx falava, portanto, e não de todo e qualquer Estado.

Para não antecipar um Marx revolucionário e ter uma idéia mais nítida de sua posição política neste momento - a de um liberal radical, mas ainda não a de um comunista - vale a pena aproximar-se de um pequeno manuscrito, referente à questão da "centralização" do Estado, que escreveu em polêmica com Moses Hess. Afirmava Hess que se os homens fossem de acordo com a sua natureza a liberdade individual não seria senão a liberdade universal. Filosoficamente a questão da autoridade do Estado seria, então, uma não questão, uma vez que o poder central viveria em todo e em cada um dos membros da comunidade, toda legislação externa, poder positivo ou, até mesmo poder do Estado seria supérfluo: "Uma sociedade assim não seria um Estado, mas um ideal da humanidade", afirmava Hess, para quem essa não era apenas uma questão teórica e sim uma "resposta prática" à questão da centralização do poder político (apud idem, p.184).

A própria questão da autoridade do Estado, tal qual era formulada por Hess seria equivocada, segundo Marx. A formulação do problema era mais importante do que a própria resposta, na medida em que era ele quem representava a dificuldade capital. Uma resposta seria possível apenas para uma questão real, ou seja, para um problema que não fosse individual, ou do filósofo, mas supraindividual, ou filosófico, dizendo assim respeito a toda a época. Marx protestava, assim, em nome da filosofia contra a idéia do fim do Estado presente no artigo de Hess: "A filosofia deve protestar seriamente quando é confundida com a imaginação. (..) O autor substitui a filosofia por 'suas abstrações'" (ibidem).

Neste momento, o Estado que merecia anular-se era para Marx aquele que estava em oposição a seu dever ser, que era desconforme a seu conceito, e, desse modo, já configuraria um não-Estado. Embora as conclusões po- 
líticas às quais chegava não fossem iguais àquelas de Hegel, Marx não estava, no que se refere a uma definição do Estado, muito distante do velho mestre. Pois era com os olhos no horizonte utópico do Estado racional que Marx se punha a ver a política neste momento (cf. p.ex. ABENSOUR, 1998, pp.33-43 e TEEPLE, 1984, pp.27-45).

Era esse Estado racional que fornecia a medida que permitia a crítica do real. O procedimento crítico era aquele explicitado ainda em 1841: a comparação da existência singular do Estado a sua essência racional. Assim, escrevendo contra a idéia de "Estado cristão", defendida no editorial do número 179 da Kolnische Zeitung, em julho de 1842, enfatizava a necessidade de tomar como ponto de partida a própria natureza da sociedade humana e do Estado, sua essência, para estabelecer a justiça das constituições estatais e realizar a liberdade racional. Nessa perspectiva, escrevia Marx,

se os primeiros filósofos do direito público fizeram derivar o Estado dos impulsos da ambição ou do instinto social, ou ainda da razão, mas não da razão da sociedade, mas daquela do indivíduo, o ponto de vista mais ideal e profundo da mais recente filosofia o fez derivar da idéia do todo. Tal filosofia considera o Estado como um grande organismo no qual a liberdade jurídica, ética e política deve alcançar a própria realização e na qual o simples cidadão, obedecendo às leis do Estado obedece apenas às leis naturais de sua própria razão, da razão humana. (MARX \& ENGELS, 1980, p.204)

O conceito de Estado ganharia, portanto, autonomia perante as determinações próprias da vida religiosa ("a natureza da sociedade cristã"). Liberando-se de pressupostos teológicos a política poderia manifestar seu conteúdo racional, como sede da razão da liberdade. Tratava-se de conquistar para a política a mesma autonomia que a física, a matemática e a medicina, por exemplo, haviam conquistado, investigando sua essência nas determinações da natureza da sociedade humana. Não é, portanto, de se estranhar que Marx cite Maquiavel como um dos precursores dessa luta filosófica que se caracterizava por desenvolver as leis do Estado por meio "da razão e da experiência" (idem, p.203). ${ }^{8}$

\section{A crítica da política como crítica filosófica}

A idéia de crítica iria ganhar novos contornos na obra de Marx após a leitura das Vorläufige Thesen zur Reformation der Philosophie (Teses provi-

8 Maquiavel, na dedicatória de Il principe assume ser seu objetivo "la cognizione delle azioni degli uomini grandi, impartata de me com una lunga esperienzia delle cosse moderne e una continua lezione delle antique" (Maquiavel, 1971, p.257). 
sórias para a reforma da filosofia), escritas por Ludwig Feuerbach em 1842 e publicadas por Arnold Ruge nas Anedokte. ${ }^{9}$ Nelas Feuerbach anunciava ser Espinosa o criador da filosofia especulativa e Hegel seu realizador e, como tal, o maior dos teólogos, dado que a filosofia especulativa não seria senão teologia. Para Espinosa o predicado da substância seria a própria substância, assim como para Hegel o predicado do absoluto, o sujeito em geral, seria o próprio sujeito. O absoluto nunca poderia ser sujeito, afirmava Feuerbach, na medida em que este se esgotaria no predicado. Desse modo, a hipostasia do absoluto em sujeito teria como contrapartida a degradação do sujeito em predicado (Cf. ROSSI, 1971, p.139-145).

Para Hegel o pensamento era o sujeito, o ser era o predicado e a lógica era o pensamento que se pensava a si próprio, "o pensamento como sujeito sem predicado ou o pensamento que é ao mesmo tempo sujeito e predicado de si próprio" (FEUERBACH, 1960, p.160-161). Feuerbach invertia a assertiva hegeliana, afirmando que a "verdadeira relação entre o pensamento e o ser se reduz a isto: o ser é o sujeito, o pensamento é o predicado. O pensamento advém do ser, mas o ser não advém do pensamento. (..) A essência do ser enquanto ser é a essência da natureza" (ibidem). Apesar de Hegel, o absoluto continuaria sendo no fundo o verdadeiro, a determinação, o suporte do predicado. Daí a necessidade de inverter da filosofia especulativa hegeliana, restituindo aos sujeitos reais a sua condição primeira:

O método da crítica reformadora da filosofia especulativa em geral não se distingue do método já empregado na filosofia da religião. Apenas devemos fazer do predicado o sujeito, e deste sujeito o objeto e o princípio, não devemos senão inverter a filosofia especulativa para alcançarmos a verdade desvelada, a verdade pura e nua. (idem, p.141)

Foi forte o impacto que a leitura desse texto de Feuerbach exerceu sobre Marx. Tem razão Althusser ao destacar esse impacto e ao reconhecer o significado histórico da crítica feuerbachiana ao hegelianismo (Cf. ALTHUSSER, p.33-38). Inseridas no contexto da crise e decomposição da corrente hegeliana, as Vorläufige Thesen, desenvolviam um programa de crítica teórica que propunha a negação da filosofia precedente, a ruptura radical com a teologia e a fusão de uma nova filosofia com a ciência, reen-

9 Ao contrário de AVINERI (1970), HENRY (1991, p.44) destaca que a influência de Feuerbach na obra de Marx já se manifestava antes da leitura das Vorläufige Thesen. A observação é pertinente, e já apontei acima os ecos da Zur Kritik der Hegelschen Philosophie feuerbachiana. Segundo McLelland, Marx havia lido Das Wesen des Christentums quando da redação da tese doutoral em 1841, mas a impressão que havia causado nele esta obra era menor do que aquela que a mesma havia provocado em Arnold Ruge (MCLELLAND. 1990, p.81). 
contrando, assim com esta sua base material e natural. ${ }^{10}$ Mas o programa político de Feuerbach estava longe de ser revolucionário. O homem era para ele a essência fundamental do Estado, mas este continuava a ser a totalidade realizada e explicitada da essência humana. Realização esta que reconduziria as qualidades particulares dos homens à identidade com o chefe de Estado, o qual personificaria o caráter racional desse Estado reunindo em si, em sua vontade, a vontade de todos e superando, em sua universalidade, a particularidade dos indivíduos: "O chefe de Estado é o representante do homem universal" (FEUERBACH, 1960, p.168). ${ }^{11}$ Não é de se estranhar, pois, que em uma carta a Arnold Ruge datada de 13 de março de 1843 Marx manifestasse reservas quanto ao tratamento insuficiente dado à política, reeditando uma modalidade de crítica que Feuerbach havia dirigido contra o próprio Hegel ("o limite da exposição"):

Sobre os aforismos de Feuerbach não estou de acordo apenas em um ponto, aquele no qual insiste demasiadamente sobre a natureza e muito pouco sobre a política. Apesar disso, esta é a única aliança por meio da qual a filosofia atual pode tornar-se uma verdade. Mas provavelmente deverá, como no século XVI, quando aos entusiastas da natureza correspondia uma outra série de entusiastas do Estado. (MARX \& ENGELS, 1980, p.419-420)

É com base neste método apresentado por Feuerbach em seus textos voltados para a conformação da reforma da filosofia que Marx iniciará seu trabalho de revisão crítica da filosofia do direito de Hegel. Já não se tratava mais de cotejar, por meio da crítica filosófica, a utopia do caráter racional do Estado moderno e a conseqüente universalidade do direito com a inadequação e a irracionalidade do real. A insuficiência desse procedimento havia ficado clara para Marx à medida que se aproximava, com sua atividade de jornalista, dessa realidade irracional que pretendia denunciar.

Foi na série de artigos a respeito do roubo de lenha, publicados na Reinische Zeitung, que o jovem Marx levou esse procedimento crítico a seu ponto de máxima tensão, contrapondo o caráter universal do Estado à particularidade da propriedade privada. Os artigos sobre o roubo de lenha e o desenvolvimento dado neles à questão da relação entre a realização da razão universal e a manifestação do interesse particular, não deixavam de revelar

10 Henry assinala de modo apropriado que para Marx o fim da filosofia tem aqui um alcance limitado e visa, apenas, à filosofia hegeliana (HENRY, 1991, p.15).

11 A afirmação não está distante do Hegel das Linhas fundamentais: "A personalidade e a subjetividade em geral como infinitas se referem a si mesmas, só possuem verdade ou, pelo menos, verdade imediata, como pessoas, como sujeitos que existem para si, e aquilo que existe para si é necessariamente um. A personalidade do Estado só é real como uma pessoa: o monarca" (HEGEL, 1995, § 279, p.311). 
seu ceticismo perante a capacidade do Estado prussiano resistir à colonização por parte desses interesses e evitar sua "degradação" (idem, p.240; cf. LÖWY, 2002, p.73). Ceticismo esse que foi potencializado com a interdição da Reinische Zeitung em janeiro de 1843, em reunião do conselho de ministros com a presença do rei, fato que provocou a demissão de Marx e um desabafo pouco usual em carta a Ruge do mesmo mês: "É ruim fazer um trabalho servil, ainda que em nome da liberdade, e combater com alfinetadas ao invés de com marretas. Estou cansado da hipocrisia, da estupidez, da autoridade brutal e de submetermo-nos, retirarmo-nos, dobrarmo-nos e discutirmos sobre palavras" (MARX \& ENGELS, 1980, p.417). O alvo de Marx não era apenas as autoridades estatais. Suas ásperas palavras estavam dirigidas contra seus antigos aliados da Reinische Zeitung, a burguesia liberal, e sua atitude servil perante a censura e o Estado prussiano (cf. LÖWY, 2002, p.75). Em carta ao mesmo destinatário de março de 1843, o tom indignado ainda permanecia, mas assumia a forma de denúncia e programa político:

ninguém se engana mais sobre este sistema e sua simples natureza. (..) O hábito imponente do liberalismo caiu e aos olhos de todo o mundo, encontra-se, em toda sua nudez, o mais repelente despotismo. Também esta é uma revelação, embora invertida. É uma verdade que, pelo menos, ensina a conhecer a vacuidade de nosso patriotismo, a monstruosidade de nosso Estado e a escondermos o rosto. (MARX \& ENGELS, 1976, p.147)

O ceticismo com o Estado prussiano convertia-se, ao final da carta em um surpreendente otimismo para com o destino da Alemanha: "Esse destino é a revolução, a revolução que é iminente" (idem, p.148). Ruge não partilhou o mesmo entusiasmo, o que fez seu jovem amigo voltar à carga: "Sua carta, caro amigo é uma boa elegia, um canto fúnebre que corta a respiração; mas politicamente não vale nada" (idem, p.148). As esperanças depositadas por Marx no desenvolvimento da política alemã encontravam seu suporte histórico nas tendências sociais colocadas em movimento pelo capitalismo moderno: a moderna indústria e o comércio, o sistema de propriedade privada e a exploração dos homens, dilaceravam a velha ordem e estimulavam a ruptura em seu interior.

Não era, entretanto, do desenvolvimento mecânico das contradições da sociedade capitalista que nasceria o novo. Tal desenvolvimento não seria, senão, a manutenção da inversão entre sujeito e predicado completada pela transformação da indústria e do comércio em sujeito. Para Marx, pelo contrário, a força capaz de romper com a velha ordem nascia do encontro da "humanidade sofrente que pensa [der leidenden Menschheit, die denkt] e da humanidade pensante que é oprimida [der denkenden Menschheit, die unterdrückt wird] " (idem, p.153). Era na aliança dos filósofos críticos com 
os explorados que Marx vislumbrava o novo sujeito da nova ordem. Era tudo uma questão de tempo: tempo para a humanidade pensante criticar e revelar a todos a irracionalidade do velho mundo; tempo para a humanidade sofrente reunir-se e concentrar-se.

A direção de tal aliança caberia, entretanto, no esquema de Marx, à "humanidade pensante". Seria ela quem ocuparia um papel ativo, enquanto a "humanidade sofrente" encontrar-se-ia presa a sua passividade. As opções terminológicas de Marx revelam isso. Löwy (2002, p.85-86) assinala que ao contrário da simples adoção de forma estilística da "reviravolta", da qual faz uso corrente ("O momento filosófico não é a lógica da coisa, mas a coisa da lógica", por exemplo, cf. abaixo), desta vez Marx recorre a um recurso semântico que explicita a diferença. Ao invés contrapor a humanidade sofrente que pensa à humanidade pensante que sofre, como seria de se esperar, esta última aparecia no texto como oprimida e não sofrente. A conotação de passividade que o vocábulo alemão Leiden (sofrer, padecer) carrega era, por meio desse recurso, deslocada para fora do pensamento, tornando desse modo possível sua revolta.

Revelar a irracionalidade do velho mundo era, também, encarar sua filosofia. Aquela crítica à filosofia do direito de Hegel, tantas vezes adiada exigia, agora, ser enfrentada. Depois da supressão da Rheinische Zeitung, no começo de 1843, Marx partiu para Bad Kreuznach, onde a família de sua esposa, Jenny Marx, possuía uma casa de verão. Foi durante esse retiro que escreveu as páginas conhecidas como Zur Kritik der Hegelschen Rechtsphilosophie [Crítica da Filosofia do Direito de Hegel], texto que marcará uma importante inflexão em seu pensamento. Nele começou a ganhar contornos sua adesão ao comunismo. ${ }^{12}$

12 Na datação estabelecida por Riazanov na primeira edição de 1927 e aceita pela maioria dos comentadores, a crítica de Marx a filosofia do direito de Hegel teria sido escrita entre a primavera e o verão (do hemisfério Norte) de 1843. Rubel, por exemplo, afirma que foi em Kreuznach entre os meses de maio e outubro de 1843 que Marx completou o texto, muito embora considere admissível que tenha começado a trabalhar nele um ano antes (RUBEL, 1982, p.865) HENRY (1991, p.44), entretanto, afirma que esse manuscrito teria sido composto em 1842, mas tal afirmação não encontra amparo em fontes documentais (nem em Marx que afirma ter escrito o texto em Bad Kreuznach, onde a família de sua esposa, Jenny Marx, possuía uma casa de verão e onde só chega depois da supressão da Rheinische Zeitung, no começo de 1843).De acordo com HUNT (1978), foi Shlomo AVINERI (1970) quem identificou pela primeira vez, de maneira consistente, esse texto como o ponto no qual a adesão de Marx ao comunismo ocorre. Antes de Avnieri, tal adesão era datada em 1844 e localizada espacialmente em Paris, para onde Marx foi ao final de 1843 e onde participou da redação dos Deutsch-Französische Jahrbücher, juntamente com Arnol Ruge. Para NICOLAIEVSKI e MAENCHEN-HELFEN, "os Deutsch-Französische Jahrbücher são o ultimo produto do jovem-hegelianismo não só porque depois de sua publicação os jovens-hegelianos não levantaram mais a voz, como também porque não tinham mais o que dizer. O jovem-hegelianismo se converte no comunismo (1973, p.96) 
Em Kreuznach, Marx teve a oportunidade não só de abordar de maneira mais sistemática a filosofia do direito de Hegel, como de refletir sobre a situação política alemã e européia. Foi, entretanto, ainda sob a forma de uma crítica filosófica que Marx empreendeu seu projeto. Seu programa de pesquisa estava claramente inspirado nas Vorläufige Thesen feuerbachianas e na exigência que estas faziam de inverter o pensamento hegeliano, trazendo aquilo que ele punha como predicado para a posição de sujeito real (cf. AVINERI, 1970, p.10-13). ${ }^{13}$ A inspiração beira a literalidade em vários momentos, como naquele em que Marx protestava: "O que é relevante é que Hegel, a todo momento, faz da idéia o sujeito e do sujeito propriamente dito, real, como o 'sentimento político' faz o predicado" (MARX \& ENGELS, 1976, p.11). Aquilo que deveria ser o sujeito da idéia transforma-se em Hegel em um produto, um predicado da própria idéia. Assim, em sua investigação a respeito da filosofia do direito Hegel afasta-se da determinação de um conceito do Estado para fazer do estado do Conceito, o objeto da pesquisa: "Do sujeito da idéia faz um produto, um predicado da idéia. Ele não desenvolve seu pensamento a partir do objeto, mas desenvolve o objeto segundo um pensamento previamente concebido e concebido previamente na esfera abstrata da lógica" (idem, p.15).

A reflexão hegeliana aparecia, assim, como um post scriptum à Wissenschaft der Logik (Ciência da lógica): "O momento filosófico não é a lógica da coisa, mas a coisa da lógica. A lógica não serve para demonstrar do Estado, mas o Estado serve para demonstrar a lógica. (..) Omitindo as determinações concretas (..) temos diante de nós um capítulo da lógica" (idem, 1976, p.19; Marx, 2005, p.39). Caberia a crítica filosófica transformar essa reflexão para reencontrar em meio ao misticismo as determinações materiais dos conceitos que se faziam presentes no âmbito da filosofia do

13 TEEPLE (1984, p.47-48) procura minimizar a influência desses textos e, principalmente das Vorläufige Thesen sobre Marx, argumentando que Avineri não teria acrescentado argumento algum para sustentar sua tese, a não ser a analogia entre o procedimento metodológico de Feuerbach e o de Marx. A analogia, entetanto, beira a literalidade em alguns pontos, o que deveria bastar para dar força ao empreendimento de Avineri. Ao argumento da analogia posso acrescentar a já citada carta a Ruge, na qual Marx se põe de acordo com Feuerbach e destaca a necessidade de aplicar seu método à política (cf. MARX \& ENGELS, 1980, p.418-420), bem como a passagem dos Ökonomisch-philosophische Manuskripte (Manuscritos econômico-filosóficos) de 1844: "A crítica positiva em geral, incluindo também a crítica positiva alemã da economia política, deve sua verdadeira fundação às descobertas de Feuerbach, contra cujas 'Filosofa do futuro' [Grundsätze der Philosophie der Zukunft] e "Teses para a reforma da filosofia' [Vorläufige Thesen zur Reformation der Philosophie ] nas 'Anedokta' - ainda que tacitamente utilizadas - a inveja de uns e o ódio real de outros parecem ter suscitado um complô formal de silêncio" (MARX \& ENGELS, 1976, p.252). Foi também nesses manuscritos que Marx reconheceu que havia sido Feuerbach com as Vorläufige Thesen e os Grundsätze quem havia "derrotado a velha dialética e filosofia" (MARX \& ENGELS, 1976, p.355) 
direito de Hegel. Marx aceitava, entretanto, como parte do procedimento crítico as categorias hegelianas fundamentais - como sociedade civil e propriedade - tal e qual apareciam nas Grundlinien der Philosophie des Rechts para, a seguir, encontrar suas determinações reais reconstruindo sua materialidade (cf. AVINERI, 1970 e MERCIER-JOSA, 1986). A crítica da política desenvolvida por Marx era, assim, rigorosamente uma crítica filosófica. Segundo afirmava:

a crítica verdadeiramente filosófica da constituição hodierna do Estado não indica somente contradições existentes; mas as explica, compreende sua gênese, sua necessidade. Ela as apreende em seu significado peculiar. Esse compreender não consiste, como pensa Hegel, em reconhecer em todo lugar as determinações do conceito puro [logischen Begriffs], mas em conceber a lógica específica do objeto específico. (MARX \& ENGELS, 1976, p.103)

A crítica à teoria da soberania de Hegel, é a esse respeito exemplar. A contrapelo do contratualismo rousseauniano, que erigia o poder soberano sobre os ombros da vontade geral, Hegel fazia do poder soberano o sujeito para, a seguir, produzir a ilusão de que o príncipe era o senhor desse momento. Marx conduzia a crítica a essa inversão segundo procedimento metodológico feuerbachiano já citado. Afirmava que

Hegel dá uma existência independente aos predicados, aos objetos, mas abstraindo do próprio sujeito que é realmente independente. Depois, o sujeito real aparece como o resultado, ao passo que se deveria partir do sujeito real e considerar o seu objetivar-se. A substância mística torna-se, então, o sujeito real e o sujeito real aparece como outra coisa, como um momento da substância mística. (idem, p.26)

Tal procedimento permitia a Hegel apresentar o monarca como o "homem-Deus real, como a encarnação real da idéia" (idem, p.27). Se para o "homem comum", o monarca possuía o poder soberano e a soberania, para o filósofo alemão esta relação entre o poder e seu sujeito aparecia invertida: "A soberania do Estado é o monarca" (idem, p.26). Esse procedimento tinha por resultado uma ilusão, mas uma ilusão conforme a sua época, uma ilusão historicamente determinada. A imagem que toda monarquia constitucional da Europa fazia a respeito de si própria era transformada por Hegel em "absolutas autodeterminações da vontade" (idem, p.27).

Porém, Marx não criticou Hegel por este fazer uma descrição das instituições políticas do século XIX vazada em um vocabulário especulativo, criticou-o por transformar essas mesmas instituições - e principalmente a monarquia constitucional - na essência do próprio Estado (cf. AVINERI, 1970, p.16). Ao levar adiante esta crítica seu argumento a respeito da filosofia hegeliana articulou-se a uma crítica das bases políticas dessa filosofia, o Es- 
tado moderno. A crítica filosófica tornava-se, assim também uma crítica da política e da sociedade da época. ${ }^{14}$

Com essa transformação a crítica marxiana assumia contornos radicais, mostrando a evolução de suas atitudes e idéias políticas. À teoria hegeliana da soberania da qual o monarca era a encarnação, Marx contrapunha a idéia de que apenas a soberania do povo era verdadeira soberania. Era a partir desta soberania verdadeira que poderia ter lugar a "verdadeira democracia":

A democracia é a verdade da monarquia, a monarquia não é a verdade da democracia. A monarquia é necessariamente democracia como inconseqüência perante si própria, o elemento monárquico não é um inconseqüência na democracia. A monarquia não pode ser concebida em si mesma, a democracia pode. Na democracia nenhum de seus elementos adquire um significado diverso daquele que se espera. Cada um é realmente apenas um momento de toda a demos, Na monarquia uma parte determina o caráter do todo: a constituição em se conjunto deve-se modificar segundo um ponto fixo. A democracia é o gênero da constituição. A monarquia é uma espécie e uma espécie má. A democracia é conteúdo e forma. A monarquia deve ser apenas forma, mas esta altera o conteúdo.

Na monarquia o todo, o povo, é subsumido sob um de seus modos de existência, a constituição política; na democracia a própria constituição aparece simplesmente como uma determinação, isto é, autodeterminação do povo. Na monarquia temos o povo da constituição; e na democracia a constituição do povo. A democracia é o enigma resolvido de todas as constituições. (MARX \& ENGELS, 1976, p.33)

A critica da política encontrava seu lugar como uma negação da política existente. Nela o povo era o único concreto; era o sujeito do qual o Estado político não era, senão, o predicado, uma forma de existência particular do povo. Em Hegel, o monarca era a encarnação da idéia de Estado; em Marx, o Estado político era a desencarnação do povo. O tema do "fim do Estado" assumia agora uma nova forma no interior do pensamento marxiano. No momento em que o povo passava a ser o Estado, aquela separação existente entre o Estado e a sociedade encontrava seu fim. A crítica de Marx dirigiase, claramente, contra a abstração da política moderna, ou seja, contra a separação do Estado político da sociedade civil, e contra a abstração da cidadania moderna que afirmava uma liberdade e a igualdade que apareciam fora de todo contexto social e que, portanto, não eram senão liberdades e igualdades aparentes (cf. ARTOUS, 1999, p.27). A superação da política como abstração significa que o "o Estado político desaparece" (MARX \&

14 Cf. AVINERI (1970). Para Boris NICOLAIEVSKI e Otto MAENCHEN-HELFEN, nesse ponto a "crítica do Estado se converte em crítica da sociedade. Penetra até o próprio fundamento da sociedade. Esse fundamento é a propriedade privada" (1973, p.95) 
ENGELS, 1976, p.34), mas também que a sociedade civil, concebida como uma esfera diferenciada dos interesses privado, encontra também seu fim.

O argumento é surpreendente, pois retoma idéias anteriormente avançadas por Moses Hess e criticadas pelo próprio Marx (cf. acima). O desenvolvimento da crítica da filosofia hegeliana do direito coincidia, assim, claramente com uma aproximação de seu autor ao comunismo filosófico de Hess. Renegando sua crítica anterior, Marx passava a considerar que na democracia a constituição, a lei e o Estado eram expressões da autodeterminação do povo, da soberania popular. Realizada tal autodeterminação o Estado perderia sua forma política, ou seja, deixaria de estar separado da sociedade. Desse modo, a superação da separação existente entre Estado e sociedade civil era, também, uma superação da abstração (separação) do Estado político da real vida do povo. O poder soberano encontraria aí nova sede - o povo - tornando obsoleto seu antigo lugar. A crítica marxiana assumia, então, a forma de uma crítica da política como abstração, o que implicava uma crítica da política existente com vistas a sua negação.

Esse programa de uma crítica da política aparecia, de modo desenvolvido na última de suas cartas dirigidas por Marx a Arnold Ruge a respeito da criação daqueles que viriam a ser os Deutsch-Französischen Jahrbücher. ${ }^{15}$ Ao contrário do procedimento adotado pelos reformadores precedentes, que procuravam antecipar positivamente o mundo desejado, era necessário ter como objetivo encontrar o novo por meio da crítica do velho. Lançar a filosofia à luta tornava-se, desse modo, aceitar seu caráter histórico. Era aceitar na fundação da crítica a dimensão política da história. Ao contrário do que Hegel - e também Bauer - pretenderam a filosofia não estava "acima de seu tempo". Ela era a razão histórica de seu próprio tempo. No reconhecimento da dimensão política da história a nova crítica encontrava sua ata de fundação.

A mundanização da filosofia lhe permitia reconhecer essa dimensão e seu novo lugar. Os debates em torno da crítica da religião haviam trazido a filosofia e os filósofos à luz do dia. A iniciativa não pertenceu à filosofia crítica, é verdade, mas à ortodoxia, ao teísmo e à censura. Mas o ataque havia permitido aos jovens filósofos lançarem-se à imprensa para defender suas idéias e enfrentarem, pela primeira vez a opinião pública voltando-se ao exterior. Havia permitido, também, a esses mesmos filósofos, encararem a crítica interna da filosofia hegeliana, apontando seus limites e contradições e desenvolvendo um programa de reforma ou superação dela própria.

A filosofia mundana transformava-se em atividade e ativismo. Entretanto, esse ativismo era ainda filosófico. Marx considerava que não era pa-

15 A primeira das cartas de Marx a Ruge data de março de 1843 e a última de setembro de 1843. 
pel dos filósofos construírem o futuro de acordo com projetos há muito guardados nas gavetas de seus gabinetes. Por essa razão, rejeitava o comunismo de Cabet, Dézamy e Weitling qualificando-o de "uma abstração dogmática". A utopia do estado racional, abandonada por Marx não dava lugar a uma nova utopia e sim a uma crítica radical. A atividade da filosofia deveria estar voltada para o presente: "a crítica sem preconceitos de tudo o que existe" (MARX \& ENGELS, 1976, p.154). ${ }^{16}$

Essa crítica não era mais, entretanto, a denúncia da inadequação existente entre a irracionalidade do real e a utopia do caráter racional do Estado moderno. Os limites desse procedimento já haviam se revelado por ocasião dos artigos de Marx referentes aos roubos de lenha. O empreendimento de crítica da filosofia do direito de Hegel havia, por sua vez, permitido a construção de uma nova modalidade de crítica que se interrogava a respeito do significado particular dessa inadequação procurando reconstruir a lógica específica do objeto. ${ }^{17}$ Essa nova crítica lhe permitia agora identificar que a razão existia também naquilo que não era racional. A irracionalidade do real não era mais uma contradição externa ao Estado racional, era a própria premissa real do Estado político. A contradição entre a determinação ideal do Estado racional e suas premissas reais era, desse modo, um conflito do Estado político com ele mesmo (idem, p.155).

Compreendido como o predicado da vida social o Estado político condensaria "no interior de sua forma sub specie rei publicae todas as lutas, as necessidades e a verdade social" (ibidem). A crítica do presente não poderia, pois, se furtar à "crítica da questão política mais particular", ao exame crítico das instituições políticas existentes e à tomada de posição política (partidária) que nascia dessa atitude. Ao filosofo caberia retirar o véu ilusório que cobria a política e mostrar ao mundo, aquilo que o mundo já sabia, "trazendo à forma humana autoconsciente todas as questões políticas e religiosas" (idem, p.156). A reforma da consciência seria, assim, o resultado da análise da consciência mística, permitindo o reencontro dela com sua verdade interior:

Tornar-se-á então claro como o mundo possui há tempo o sonho de uma coisa da qual bastaria possuir a consciência para possuí-la realmente. Tornar-se-á claro como não se trata de traçar uma linha divisória entre o passado e o futuro e sim de

16 Comparar com a já citada passagem de Bruno Bauer em Die Posaune; "A filosofia é, consequentemente, a crítica daquilo que existe" (BAUER, 1972, p.105).

17 Alguns comentadores (p.ex. HUNT, p.31-44 e RANCIËRE, 1979, p.77-81) tendem a tratar os textos do período 1841-1843 de modo a homogeneizá-los, encontrando de modo fantasioso na Zur Kritik der Hegelschen Rechtsphilosophie marxiana, ou na correspondência com Ruge, a mesma modalidade de crítica da tese doutoral. 
realizar os pensamentos do passado. Mostrar-se-á, enfim, como a humanidade não começa um trabalho novo, mas leva até o fim, conscientemente, seu velho trabalho. (ibidem)

\section{Rumo a uma crítica prática}

No que diz respeito à construção da noção de crítica da política o desenvolvimento teórico de Marx ainda encontra-se, neste ponto, incompleto. Notável é o caráter inacabado do conceito de crítica da política, tanto na abordagem marxiana da filosofia do direito como na importante troca de correspondência com Arnold Ruge. Nesta, a crítica da política ainda era uma crítica autolimitada a uma prática filosófica. Mas o caráter inacabado do conceito de crítica da política não impede de perceber nele questões e até mesmo respostas que terão longo curso na reflexão marxiana. A ruptura que tem lugar nos manuscritos de Kreuznach com a com a utopia do Estado racional permite a Marx conceber uma crítica da política que não reivindicava uma medida de valor externa ao estava sendo criticado, ou seja, que não recorria a uma comparação entre seu objeto e um modelo de boa política, ou uma idéia de Estado. A crítica era, assim, uma de negação da política existente.

A relação entre teoria e prática estabelecida por Marx, entretanto, pouco se distanciava daquela anunciada por Bruno Bauer em Die Posaune. O tranqüilo gabinete de estudos de Bad Kreuznach havia permitido a Marx superar a filosofia hegeliana do Direito e do Estado. Mas faltava, ainda, encontrar o fundamento político da crítica da política. Para romper com os limites autoimpostos à crítica, Marx deveria encontrar, nas buliçosas ruas de Paris, os novos personagens de uma nova prática política, o sujeito histórico do comunismo.

BIANCHI, A. The mundanization of philosophy: Marx and the origins of the criticism of politics. Trans/Form/Ação, (São Paulo), v.29(2), 2006, p.43-64.

- ABSTRACT: The aim of this article is to present the origins of the marxian criticism of politics. Finding its place between the years of 1842 and 1843, this criticism emerges from within a review of the hegelian philosophy and takes is first form as a philosophical criticism of politics. The criticism of politics developed by Marx was, thus, rigorously a philosophical undertaking, yet of a philosophy that took the world as its object and flowed outwardly, manifesting itself externally as a criticism of the society of that time and a negation of the existing politics.

- KEYWORDS: Marx; Hegel; german ideology. 


\section{Referências bibliográficas}

ABENSOUR, Miguel. A democracia contra o estado: Marx e o momento maquiaveliano. Belo Horizonte : UFMG, 1998.

ALTHUSSER, Louis. A favor de Marx. Rio de Janeiro: Zahar, 1979.

ARTOUS, Antoine. Marx, l'Etat et la politique. Paris: Syllepse, 1999.

AVNIERI, Shlomo. The social and political thought of Karl Marx. Cambridge: Cambridge University, 1970

BAATSCH, H.-A.. Introduction. In: BAUER, Bruno. La trompette du jugement dernier contre Hegel, l'athée er l'antéchrist: un ultimatum. Paris: Aubier-Montaigne, 1972, p. 7-27.

BAUER, Bruno. La trompette du jugement dernier contre Hegel, l'athée er l'antéchrist: un ultimatum. Paris: Aubier-Montaigne, 1972.

CINGOLI, Mario. Hegel, Marx, Ilting: critica della critica della critica. Quaderni Materialisti, Milano, n. 3/4, p.253-262, 2004-2005.

FEUERBCAH, Ludwig. Manifestes philosophiques: texts choisis (1939-1945). Paris: PUF, 1960

HEGEL, G. W. F.. Príncipes de la philosophie du droit. traduit de l'allemand par André Kaan et préfacé par Jean Hyppolite. Paris: Gallimard, 1995.

HENRY, Michel. Marx I: une philosophie de la réalité. Paris: Gallimard, 1991.

HONDT, Jacques d'. Hegel en son temps: Berlin, 1818-1831. Paris: Sociales, 1968.

HUNT, Richard. The political ideas of Marx and Engels. Pittsburgh: Pittsburgh University, 1974, $2 \mathrm{v}$.

ILTING, Karl-Heins. Hegel diverso: le filosofie del diritto dal 1818 al 1831. Roma/ Bari: Laterza, 1977.

LOSURDO, Domenico. Hegel, Marx e a tradição liberal: liberdade, igualdade, Estado. São Paulo: Unesp, 1998.

LÖWY, Michael. A teoria da revolução no jovem Marx. Petrópolis: Vozes, 2002.

MAQUIAVEL, Nicolau. Tutte le opere. Florença: Sansoni, 1971.

MARX, Karl \& ENGELS, Friedrich. Opere di Marx ed Engels: 1835-1843, v.I. Roma: Riunite, 1980.

Opere di Marx ed Engels: 1843-1844, v.III. Roma: Riunite, 1976

McLELLAND, David. Marx: vida e pensamento. Petrópolis: Vozes, 1990.

MERCIER-JOSA, Solange. Retour sur le jeune Marx: deux etudes sur le rapport de Marx a Hegel dans les manuscrits de 44 et dans le manuscrit dit de Kreuznach. Paris: Meridiens, 1986.

NICOLAIEVSKI, Boris \& MAENCHEN-HELFEN, Otto. La vida de Carlos Marx. El hombre y el luchador. México D.F.: Ayuso, 1973

RENAULT, Emmanuel. Marx et l'ieée de critique. Paris: PUF, 1995.

RANCIÈRE, Jacques. O conceito de crítica e a crítica da economia política dos Manuscritos de 1844 a O capital. In: ALTHUSSER, Louis et al. Ler O capital. Rio de Janeiro: Zahar, 1979, v.1, p.75-172. 
ROSSI, Mario. La génesis del materialismo histórico: 1. la izquierda hegeliana. Madri: Alberto Corazón, 1971.

RUBEL, Maximilien. Critique de la philosophie politique de Hegel: Notice. In: MARX, Karl. Fsuvres. Philosophie: edition établie, présentée et annotée par Maximilien Rubel. Paris: Gallimard, 1982, t. III, p.865-869.

TEEPLE, Gary. Marx's critique of politics. Toronto: University of Toronto, 1984. 